\title{
Why do entrepreneurs open tech startups? A comparative study between Brazilian and
} foreign enterprises

\author{
Lasso, Sarah Venturim; Mainardes, Emerson; Motoki, Fabio
}

Published in:

The International Entrepreneurship and Management Journal

Link to article, DOI:

$10.1007 / \mathrm{s} 11365-017-0445-8$

Publication date:

2019

Document Version

Peer reviewed version

Link back to DTU Orbit

Citation (APA):

Lasso, S. V., Mainardes, E., \& Motoki, F. (2019). Why do entrepreneurs open tech startups? A comparative study between Brazilian and foreign enterprises. The International Entrepreneurship and Management Journal, 15(1), 233-255. https://doi.org/10.1007/s11365-017-0445-8

\section{General rights}

Copyright and moral rights for the publications made accessible in the public portal are retained by the authors and/or other copyright owners and it is a condition of accessing publications that users recognise and abide by the legal requirements associated with these rights.

- Users may download and print one copy of any publication from the public portal for the purpose of private study or research.

- You may not further distribute the material or use it for any profit-making activity or commercial gain

- You may freely distribute the URL identifying the publication in the public portal 


\title{
Why do entrepreneurs open tech startups? A comparative study between Brazilian and foreign enterprises.
}

\author{
Sarah Lasso \\ Management Engineering \\ Danmarks Tekniske Universitet \\ Produktionstorvet - Building 424 \\ 2800 Kongens Lyngby \\ sarahvlasso@gmail.com \\ Emerson Mainardes \\ FUCAPE Business School \\ Av. Fernando Ferrari, 1358 \\ Vitoria, ES, Brazil 29075-505 \\ emerson@fucape.br \\ Fabio Motoki (corresponding author) \\ FUCAPE Business School \\ Av. Fernando Ferrari, 1358 \\ Vitoria, ES, Brazil 29075-505 \\ $+55-27-4009-4444$ \\ fmotoki@fucape.br
}

This research identifies and compares the reasons that lead entrepreneurs to open a startup in Brazil or abroad along six factors: self-realization, financial, independence, innovation, roles, and recognition. Understanding differences between entrepreneurs in distinct settings may help designing better entrepreneurship policies and more effective support for nascent businesses, as well as providing better guidance to investors. Entrepreneurs who own technological startups answered an online questionnaire about the reasons for entrepreneurship through technological startups. Respondents ranked each statement using a Likert scale from (1) completely disagree to (5) completely agree. Of the respondents, 325 were Brazilian and 130 were foreigners. Results show that top-ranked reasons are mostly similar across groups, with four of the top five reasons being common. However, comparatively, they score several reasons differently. These results highlight the different reasons to enterprise between people from different countries, supporting the importance of studying the entrepreneurial phenomenon in emerging economies, which differ substantially from developed ones. They also may help conciliating conflicting results of the reasons to enterprise literature.

Keywords: Entrepreneurship. Technological startups. International comparative study. Reasons. Motives.

Version accepted on Apr $26^{\text {th }} 2017$

Published version available at https://link.springer.com/article/10.1007/s11365-017-0445-8

DOI: $10.1007 / \mathrm{s} 11365-017-0445-8$ 


\section{Introduction}

What are the reasons that lead entrepreneurs to open a startup in Brazil along self-realization, financial, independence, innovation, roles, and recognition factors? How do Brazilian entrepreneurs compare to foreign entrepreneurs along these factors? This research aims at answering these questions using these six factors. Then, through the comparison of these reasons with the ones identified in other countries, it seeks a better understanding of the behavior of Brazilian entrepreneurs in relation to their peers abroad.

This paper attempts to fill a gap in the entrepreneurship literature. Autio et al. (2001), Carter et al. (2003) and Chen and Elston (2013) argue that still there is no full understanding of the motivating factors that drives entrepreneurs to create startups. Furthermore, international comparative entrepreneurship studies like the present one are rare due to the difficulties as having access to other countries' entrepreneurs, lack of reliable secondary data and the high costs of conducting research abroad (Mueller and Thomas, 2001). This study also answers a call from Ferreira et al. (2016) for greater internationalization of the entrepreneurship literature, currently heavily concentrated in developed economies like the US, UK, and Netherlands. It also follows advice from Bjørnskov and Foss (2016), who argue that much is assumed regarding the homogeneity of the entrepreneurial environment, when in reality there is a considerable variability between countries.

Owners of technological startups filled an online questionnaire with both demographic data and scores on a 5-point Likert scale of several reasons for opening a startup. The final sample contains 325 Brazilian respondents and 130 foreigners. Foreign entrepreneurs are the ones that reported not being from Brazil. Results indicate that top-ranked reasons are mostly similar for Brazilian and foreign entrepreneurs. Of the top five reasons, the first four are the same across groups, although the ordering differs slightly: market opportunity, learning as a person, new challenges, and self-realization. In comparative terms, the difference in means tests indicate that Brazilians, when compared to their counterparts abroad, give greater importance to selling products they invented, market innovations, new products ideas, and the importance of the startup for the society and the market. In turn, foreigners attribute more importance to financial security, building wealth, flexibility, freedom to implement work methods, and to friends' respect. A robustness test using a Logit model corroborates these findings.

This paper's results contribute to a better understanding of the variables that influence entrepreneurship, fueling the debate of policies directed at increasing and supporting entrepreneurial activity (Birley, 1986; Bosma et al., 2012; Mueller and Thomas, 2001; Quatraro and Vivarelli, 2015; Shane, 1996; West et al., 2008; Van de Ven et al., 1984; Vivarelli, 2013). Krueger and Brazeal (1994) argue that entrepreneurs are not born ready to be entrepreneurs, but that the environment and culture shape them. Adequate policies help implementing a healthy and stimulating setting for entrepreneurship. Nascent technology-based companies and entrepreneurs are of relevant importance to reach high levels of innovation and economic growth (Oosterbeek et al., 2010; Song et al., 2008). Entrepreneurial activity can be a driver of sustainable growth, technological change, and facilitation of the globalization process, adding to the importance of this investigation in an emerging market like Brazil (Baglieri and Lorenzoni, 2014; Carayannis et al., 2006).

The discussion starts against this background with a literature review. Then, the paper describes the research methods and analyzes the results. Finally, there are concluding remarks.

\section{Literature Review}

\section{Entrepreneurial Intention}

Entrepreneurial intention differs from entrepreneurial activity or attitudes (Ahmad \& Seymour, 2008). Entrepreneurial activity entails, for instance, the creation of a business. This new business may or may not 
create value, as it depends of the strength of the opportunity, its innovative capabilities, and its creative resources (Ahmad \& Seymour, 2008). Entrepreneurial intention, in turn, predates entrepreneurial activity, and is about the factors that influence the decision to start a business (Ferreira et al., 2012; Hayton and Cholakova, 2012). This intention, in conjunction with the business idea, can create opportunities, further actions like entrepreneurial activity, or may even be abandoned (Saemundsson and Holmén, 2011). Thus, entrepreneurial intention is one of the drivers of entrepreneurial activity (Ahmad \& Seymour, 2008). Several factors may influence entrepreneurial intentions: previous experiences, financing, type of technology, the market and the entrepreneur's image (Feeser and Willard, 1989; Pillis and Reardon, 2007; Saemundsson and Holmén, 2011).

Technological startups are characterized by their persistence to achieve the desired results. Success usually means that several attempts occurred in spite of all obstacles encountered, which supports the hypotheses of intentional actions in the creation process (Koellinger et al., 2007; Shaver et al., 2001). Hayton and Cholakova (2012) conclude that intentions are, above all, attitudes and perceptions of entrepreneurs.

In the United States, where business and entrepreneurship are seen as a social welfare and there are incentives to enterprise (Shane, 1996), a great percentage of 18 to 64 years-old adults are engaged in some kind of entrepreneurial activity (Friedman and Aziz, 2012). The Schumpeter Model provides an explanation for the American entrepreneurship phenomenon. The model says that entrepreneurs establish their firms where other people cannot see the opportunities, and that they see new inventions as new business opportunities (Shane, 1996).

In Brazil, programs that teach and show the needed abilities for entrepreneurs are nurturing entrepreneurship intention. One example is Empretec, a program run by Sebrae, which helps individuals willing to start their own business and have entrepreneurs' characteristics (Ramlow Campelli et al., 2011). Pillis and Reardon (2007) show that self- consistency is an important predictor of entrepreneurial intention, as well as persuasive messages about careers and culture, emphasizing the importance of an environment conducive of entrepreneurship.

\section{Entrepreneurship comparative studies}

Cowling (2000) investigates if entrepreneurs within the European Union are different across countries, and find differences in age, gender and education. In the UK and Sweden, the typical entrepreneur is older and male. In Greece and Spain, the typical entrepreneur is poorly educated, while in Italy the average entrepreneur is highly educated.

Mueller and Thomas (2001) study entrepreneurs from nine countries in Latin America, Asia and Eastern Europe. They find that the country's culture influences the values, attitudes and beliefs of its entrepreneurs, providing an explanation for the different proportions of potential entrepreneurs across countries. Their results also show a positive correlation between frequency of potential entrepreneurs and the rate of new venture openings.

When comparing United States and India, Stewart et al., (2008) find that Indian and American entrepreneurs have more things in common than differences, suggesting a similar behavior on information seeking, scanning and cognition.

Focusing on emerging economies, West et al., (2008) investigate entrepreneurship in Mexico and Costa Rica. Results suggest that political instability, like in Mexico, discourage efforts in entrepreneurial activity, while social networks and the acquisition of knowledge and tangible resources can aid the development of new ventures. However, although political stability may be a necessary condition for entrepreneurship to thrive, it does not seem to be sufficient, as Costa Rica does not show outstanding entrepreneurial activity (West et al., 2008).

Gupta and Fernandez (2009) gather data on India, Turkey and United States to study the cross-cultural similarities and differences in the characteristics that are associated with entrepreneurs. They find that people attribute competence, strength, need for achievement, self-reliance, curiosity, intelligence and logical skills to entrepreneurs from all the studied countries. 
Del Junco and Brás-dos-Santos (2009) analyze differences between entrepreneurs from Germany, Italy and Spain. Spanish entrepreneurs create businesses because of personal dissatisfaction, to seize an opportunity, for ambition, independence, experience and to fulfil a need. German entrepreneurs cite ambition, seize an opportunity, family tradition, independence, interest and need as reasons to open a business. Italians entrepreneurs state ambition, seize an opportunity, independence and enjoyment. Overall, German, Italian and Spanish entrepreneurs show a similar pattern of reasons (Del Junco and Brás-dos-Santos, 2009).

Deshpandé et al. (2013) study the relation between the founder's achievement motivation and the firm's strategic orientation and performance outcomes of American and Japanese firms. Rather counterintuitively, their results indicate that these entrepreneurs from so distinct countries have more similarities than differences. The effects show the same direction for both countries, although its magnitude varies.

Cultural characteristics as individualism, collectivism, power distance, uncertain avoidance, masculinity, femininity can reflect in the countries' entrepreneurs (Hofstede, 1984, p.83). Consequently, entrepreneurs in different countries are not a homogenous group, since different countries have different cultures and can influence and encourage different people to become entrepreneurs (Cowling, 2000).

These comparative studies indicate that different settings are related to differences in entrepreneurs' profiles and entrepreneurship levels. They support the call of Ferreira et al. (2016) for more internationalization. Ferreira et al. (2016) argue that entrepreneurship studies are disproportionately concentrated in the US, with UK and the Netherlands holding distant second and third places. These studies also support the argument of Bjørnskov and Foss (2016), that entrepreneurship studies should consider differences between industries and countries and its institutional settings. The present study focus on a single industry, namely technological businesses. It compares Brazilian entrepreneurs against foreign entrepreneurs. While it acknowledges socio-demographical aspects, as well as sub-industries within the technological industry, the relatively small foreign sample size does not allow to directly compare institutional and cultural aspects of Brazilians against other countries.

\section{Reasons for entrepreneurship}

Entrepreneurial intention has been measured in a variety of ways (Autio et al., 2001). The elements that constitute these diverse measures are either intrinsic or extrinsic factors (Dubini, 1989; Carsrud and Brännback, 2011; Friedman and Aziz, 2012). Intrinsic factors are linked to recognition of the firm and peers, while extrinsic factors involve status and financial outcomes.

Motivation, commitment and effort are among the main factors that lead individuals to start a business and become entrepreneurs (Barba-Sanchez and Atienza-Sahuquillo, 2011; Dubini, 1989). Entrepreneurship is a complex phenomenon, and it can involve not only the environment but also risk-taking people and unique and skilled individuals to open a business with fast growth prospects (Dubini, 1989; Gartner, 1990; Mueller and Thomas, 2001; Simon et al., 2000). Chen and Elston (2013) also show that market competition, the environment, personal characteristics, and culture, also play a major role on the decision to create new businesses (Chen and Elston, 2013).

One intrinsic reason plays a significant role as a reason to enterprise. Several studies report the need for achievement (self-realization). Birley and Westhead (1994) find that the "Need for Personal Development" appears as one of the main reasons for British entrepreneurs to start their businesses. Taormina and Lao (2007), using a sample of Chinese entrepreneurs, report achievement striving as one of their main entrepreneurial motivations. Using a random effect meta-analysis with 41 studies Collins et al. (2004) find that achievement motivation is linked to both entrepreneurial career and entrepreneurial performance. Jayawarna et al. (2013), using data from England, document that the need for achievement is the most important effect on the decision to start a business. Stephan et al. (2015) report that this factor was used in more than 10 studies involving motivations for entrepreneurship between 2008 and 2013. More recently, Block and Landgraf (2016) find that self-realization is positively related to the transition from part-time to full-time entrepreneurship among German entrepreneurs. 
For some people, starting a business means a path to satisfy the need to achieve financial success, economic safety, or a kind of life style (Chen and Elston, 2013; Birley and Westhead, 1994). It is an extrinsic reason, and it repeatedly appears as an important motivation for entrepreneurs (Dubini, 1989; Carsrud and Brännback, 2011; Friedman and Aziz, 2012). The urge to satisfy this need is contextual. The first dimension of the context is culture, since the reasons to start a business can differ from country to country (Chen and Elston, 2013; Hofstede, 1984). For instance, cultural factors make entrepreneurship more natural in the American context than in the Irish (Pillis and Reardon, 2007). The second dimension is the market orientation, and the last is the volatility of these reasons, which can vary in time (Chen and Elston, 2013). Jayawarna et al. (2013) report that financial success is the third most important factor among reasons to enterprise for a sample of English entrepreneurs. Stephan et al. (2015) document almost a dozen studies using financial success as a reason to enterprise.

Famous people, friends, and family members serve as a role model, and several studies indicate it as an important influence on entrepreneurial behavior. Dubini (1989) finds identifies an important class of Italian entrepreneurs, the followers of family tradition role models. Shane et al. (1991), using data from Britain, New Zealand, and Norway, reports that although there is some variation between countries, roles play an important part in the motivation of entrepreneurs. Bosma et al. (2012) find that one third of the studied Dutch entrepreneurs would not have started a startup without an influential person. It is the least important among seven factors identified by Jayawarna et al. (2013), but still accounting for 5\% of the observed variance. Stephan et al. (2015) identify at least eight studies accounting for the family \& roles factor. Using a distinct perspective, Jaskiewicz et al. (2015) report how some family firms incorporate an entrepreneurial legacy narrative, encouraging entrepreneurial behaviors on the younger generations.

Another motivational factor that is frequently cited by entrepreneurs is innovation. Shane et al. (1991) report that within their Learning factor, "To be innovative and in the forefront of new technology" loads positively as an important motivation to enterprise. Exclusively British entrepreneurs show the same pattern (Birley and Westhead, 1994). Additionally, Shane (1996) reports that the rate of technological change and the rate of entrepreneurship have a positive co-movement in the American economy. Giuri et al. (2007), based on a sample of 9017 European patented inventions, report that inventors want to show that their idea can be realized. Sahut and Peris-Ortiz (2014) posit that innovation and entrepreneurship are intimately related. As Shane (2012) puts it, innovation permeates entrepreneurship: "Entrepreneurship involves more than the Kirznerian process of discovering opportunities for profit. It also involves coming up with a business idea about how to recombine resources to exploit those opportunities, as well as the exploitation process itself".

Recognition is another often cited as an entrepreneurship motivator. According to Birley and Westhead (1994), English entrepreneurs cite it as a major reason to start their businesses, a result similar to Jayawarna et al. (2013), who report it as the fifth most important factor among seven. Shane et al. (1991) find that recognition is a top reason to enterprise among British, New Zealanders and Norwegian entrepreneurs. However, Block and Landgraf (2016) find that the motivation to achieve social recognition is negatively related to the transition from part-time to full-time entrepreneurship. Stephan et al. (2015) identify nine studies using this factor as a motivation for entrepreneurs. Other more recent studies also cite status or recognition as an important motivator for entrepreneurs (Lages et al., 2016; Marques et al., 2013).

Motives to enterprise also relate to the flexibility of the work and independence it provides. Dubini (1989) reports that one large group within Italian entrepreneurs show a great sense of independence and autonomy. Shane et al. (1991) show that all of the dimensions within their Independence factor load high for all three countries studied. More recently Jayawarna et al. (2013), using data from English disadvantaged areas, document that all the items within their flexibility factor load positively, this factor accounting for $12 \%$ of the observed variance. Stephan et al. (2015) enumerate at least 11 studies from the 2008-2013 period using the independence \& autonomy factor. Block and Landgraf (2016) show that the motivation to achieve independence relates positively to the transition from part-time to full-time entrepreneurship. Estay et al. (2013), polling entrepreneurs from Bordeuax, France, find that the need for personal independence appears at the beginning stages of entrepreneurial planning. 
Carter et al. (2003) study the reasons that lead an individual to become an entrepreneur, using the six factors discussed in this section: self-realization, financial success, roles, innovation, recognition and independence. Results, based on US data from the Panel Study of Entrepreneurial Dynamics, show that these factors account for $68 \%$ of variance. The first factor, "self-realization", comprises the notions of "I can do this", self-related goals and individual reasons. "Financial success" relates to financial security and earning money. "Roles" connects to the idea of a family tradition, and the influence of friends, influential people, and other entrepreneurs in opening a business. "Innovation" refer to creating a new or improved product and selling it, following the technology market. "Recognition" encompasses social recognition, status, and approval, whereas "independence" is about flexibility, control and freedom (Carter et al., 2003). Table 1 summarizes all these factors from extant literature.

Table 1: Factors that lead entrepreneurs to open technological startups

\begin{tabular}{|l|l|}
\hline Factors & Authors \\
\hline $\begin{array}{l}\text { Self- } \\
\text { realization }\end{array}$ & $\begin{array}{l}\text { Birley and Westhead (1994), Block and Landgraf (2016), Carsrud and Brännback } \\
\text { (2011), Carter et al., (2003), Collins et al. (2004), Dubini (1989), Friedman and Aziz } \\
\text { al. (2015), Taormina and Lao (2007) }\end{array}$ \\
\hline $\begin{array}{l}\text { Financial } \\
\text { success }\end{array}$ & $\begin{array}{l}\text { Birley and Westhead (1994), Carsrud and Brännback (2011), Carter et al. (2003), Chen } \\
\text { and Elston (2013), Dubini (1989), Friedman and Aziz (2012), Jayawarna et al. (2013), } \\
\text { Stephan et al. (2015) }\end{array}$ \\
\hline Roles & $\begin{array}{l}\text { Bosma et al., (2012), Carter et al., (2003), Dubini (1989), Jaskiewicz et al. (2015), } \\
\text { Jayawarna et al. (2013), Lages et al. (2016), Marques et al. (2013), Shane et al. (2003), } \\
\text { Stephan et al. (2015), Taormina and Lao (2007) }\end{array}$ \\
\hline Innovation & $\begin{array}{l}\text { Birley and Westhead (1994), Bosma et al., (2012), Carter et al., (2003), Dubini (1989), } \\
\text { Giuri et al. (2007), Shane (1996), Shane (2012), Shane et al. (1991), Taormina and Lao } \\
\text { (2007) }\end{array}$ \\
\hline Recognition & $\begin{array}{l}\text { Birley and Westhead (1994), Block and Landgraf (2016), Carsrud and Brännback } \\
\text { (2011), Carter et al., (2003), Dubini (1989), Friedman and Aziz (2012), Jayawarna et } \\
\text { al. (2013), Lages et al. (2016), Marques et al. (2013), Maslow (1943), Shane et al. } \\
\text { (1991), Stephan et al. (2015) }\end{array}$ \\
\hline $\begin{array}{l}\text { Block and Landgraf (2016), Carter et al., (2003), Chen and Elston (2013), Dubini } \\
\text { (1989), Estay et al. (2013), Jayawarna et al. (2013), Shane et al. (1991), Stephan et al. } \\
\text { (2015) }\end{array}$ \\
\hline
\end{tabular}

Notes: based on Carter et al. (2003) and research present in the literature review.

Block and Landgraf (2016) use the model from Carter el at. (2003) to investigate which factors drive people to move from part-time entrepreneurship to full-time entrepreneurship. They find that independence, recognition, and self-realization have a positive impact on a person switching to full-time entrepreneurship. This research also builds on Carter et al. (2003), with the different goal of comparing why Brazilians decide to enterprise compared to other nationalities.

\section{How Technological Startups Emerge}

This research defines "startup" as a nascent technological-based business that has been in the market for a short time, is able to scale, is young and has low costs, and operates in an uncertain environment, which can lead to high failure rates (Dubini, 1989; Francis and Bessant, 2005; Xavier and Cancellier, 2008).

From the potential entrepreneur perspective, the entrepreneurial process can start with one idea, along with its process of judgment and the development of the idea (Hayton and Cholakova, 2012; Shane, 1996). The entrepreneur's perception of the idea, opportunity or aspiration to start a business creates tension (Lichtenstein et al., 2007). 
As time goes by, the entrepreneur can refine and develop the initial idea into an opportunity that may be explored or not. If he decides not to explore it, the idea will never be a formal opportunity; therefore, idea and opportunity are not the same thing. However, without the idea, the opportunity does not exist (Hayton and Cholakova,2012).

The idea formation process, idea examination, and entrepreneurial intention together form a development cycle of entrepreneurial opportunity. In this cycle, the opportunity itself does not exist; it demands research, study, care and development (Hayton and Cholakova, 2012). Technological startups are born from the identification of an opportunity process along with idea generation, concept construction, prototype testing and new market introduction, the entrepreneurs seeking opportunities and finding solutions for problems (Buijs, 2008; Carter et al., 1996; Liao et al., 2005).

Technological-based nascent businesses have five development stages: gestation, planning, contract services, own products, and multiple products (Van de Ven et al., 1984). On the first stage, gestation, the founders obtain abilities and experiences that will guide them in starting a business. The second stage, planning, starts with the founders' decision of actually opening a business and starting its operations. Then it reaches the third stage, service by contract, in which the company depends on contracts to have revenue. On the fourth stage, owning products, the firm starts product development and faces difficulties to acquire a market share and find distribution channels. On the last stage, multiple products, the firm develops its own line of products (Van de Ven et al., 1984).

The creation of technological businesses depends on technological entrepreneurship. Technological entrepreneurship takes place when scientific and engineering developments generate opportunities in the field of electronics, computers, software, biotechnology and internet that allow the creation of a firm, a market or an industry, which will serve the latent needs of consumers (Beckman et al., 2012; Park, 2005). These technical developments can lead to models with competitive advantage, elevated technical patterns and lower costs, and may end up with the creation of new products and intellectual property (Beckman et al., 2012).

\section{Methodology}

Analyses derive from a quantitative approach using data obtained via questionnaires based on 5-point Likert scale questions. These questionnaires result in a cross-sectional dataset from founders or owners of startups. Hair et al. (2003) argue that such numerical approach mitigates concerns about researcher biases. The first analysis is based on descriptive statistics, followed by a regression analysis by means of a Logit model. The descriptive analysis uses scores from the individual questions. For the regression analysis, each factor is aggregated as the arithmetic mean of the scores of the questions within that factor.

The Associação Brasileira de Startups (2013) estimates that Brazil has about 10,000 technological base startups. However, this is a rough estimate, and there is no study supporting this number. In part, this uncertainty derives from the uncertainty startups face. High competition, unusual levels of pressure and lack of management skills lead many of them to go bankrupt even before they reach the market (Roure and Keeley, 1990; Van de Ven et al., 1984).

The resulting sample is based on convenience, since the research depends on the entrepreneurs completing the questionnaire (Hair et al., 2003). Respondents completed 497 questionnaires in total, from which 455 the respondent declared himself the owner of a startup. There are two groups of responses based on nationality, 325 Brazilian and 130 foreign entrepreneurs. The relatively restricted number of respondents may be partially due to the secretive nature of startups, which are wary of revealing any features of innovative products and services, thus being opaque to outsiders. Foreign entrepreneurs are the ones that reported not being from Brazil. Namely, these respondents declared to be from the United States, Portugal, Morocco, England, Romania, Chile, France, India, Netherlands, Singapore, Mexico, Sweden, Ireland, 
Colombia, Russia, Germany, Italy, Jordan, Malaysia, Poland, Estonia, Cameroon, Spain, Australia, Japan and Canada.

The questionnaire contains 28 questions. Five of the questions are of a demographical nature, asking for gender, age, education, startup market and working experience. One asks if the respondent owns a startup. Additional 22 statements come from Carter et al., (2003), and query the respondent about the reasons for entrepreneurship through technological startups. These reasons are grouped into six factors: self-realization (five statements), financial success (five statements), roles (three statements), innovation (four statements), recognition (three statements) and independence (two statements). Respondents ranked each statement using a Likert scale from (1) completely disagree to (5) completely agree. Table 2 summarizes these statements. Foreign respondents answered a version in English, while Brazilian answered a version in Portuguese.

Table 2: Dimensions and variables

\begin{tabular}{|l|l|}
\hline Factor & Variable name and reference \\
\hline \multirow{5}{*}{ Self- realization } & $\begin{array}{l}\text { Self-accomplishment (AR1) } \\
\text { New challenges (AR2) } \\
\text { Learn as a person (AR3) } \\
\text { Lead and motivate others (AR4) } \\
\text { To have power to influence a company (AR5) }\end{array}$ \\
\hline & $\begin{array}{l}\text { Financial success (FIN1) } \\
\text { Financial independence (FIN2) } \\
\text { Greater personal income (FIN3) } \\
\text { Financial security (FIN4) } \\
\text { Build wealth (FIN5) }\end{array}$ \\
\hline Independence & $\begin{array}{l}\text { Flexibility (IND1) } \\
\text { Freedom for work methods (IND2) }\end{array}$ \\
\hline \multirow{2}{*}{ Innovation } & $\begin{array}{l}\text { Create and sell new products (INOV1) } \\
\text { Follow technological innovations (INOV2) } \\
\text { Many products ideas (INOV3) } \\
\text { Market opportunity (INOV4) }\end{array}$ \\
\hline Roles & $\begin{array}{l}\text { For children to inherit (PA1) } \\
\text { Family tradition (PA2) } \\
\text { Follow examples (PA3) }\end{array}$ \\
\hline \multirow{2}{*}{ Recognition } & $\begin{array}{l}\text { Importance in market -Society (REC1) } \\
\text { Society's recognition (REC2) } \\
\text { Friends' respect (REC3) }\end{array}$ \\
\hline
\end{tabular}

Notes: Adapted from Carter et al., (2003).

A validation of the questionnaire with 10 entrepreneurs allowed to correct any issues related to understanding of the questions. The sample collection started on September 16, 2013 and finished on April 23,2014 . The questionnaire was advertised online, using social media like Facebook startup groups and profiles, LinkedIn, emails, and startup's websites, and physically during entrepreneurship events and courses. The questionnaire was also sent to accelerators, incubators, technology parks and innovation centers from Brazil and abroad in an attempt to broaden the sample of respondents.

The first tool of analysis is descriptive statistics. Mean scores provide a ranking of importance of the reasons for the respondents. Differences in means between Brazilian and foreign entrepreneurs give a glimpse on how differently these two groups rate the importance of each reason.

The second tool is regression analysis. A Logit model relates the likelihood of the entrepreneur being Brazilian or foreign according to the following specification:

$$
\operatorname{Prob}(\text { Brazilian }=1)_{1}=\beta_{0}+\sum_{f=1}^{6} \beta_{f} \cdot \text { Factor }_{f}+\sum_{k} \gamma_{k} \cdot \text { Control }_{k}+\epsilon
$$

This model indicates what characterizes a Brazilian entrepreneur in relation to his or her foreign counterpart. It extends the descriptive statistics, by including controls of socio-demographic nature, as well as the sub-industries within which these entrepreneurs operate. The dependent variable is a dummy with a 
value equal to one if the entrepreneur is Brazilian, and zero otherwise. The six factors Factor $_{f}$, selfrealization, financial success, roles, innovation, recognition and independence, are the arithmetic means of its corresponding variables, for each respondent. The betas' coefficients indicate which factors Brazilians value more (if the coefficient is significant and positive) and less (if the coefficient is significant and negative) compared to foreigners. The controls Control $_{k}$ are dummies indicating the entrepreneurs' gender, age range, education level, startup type (its sub-industry), and experience level.

\section{Data analysis}

\section{Sample Demographics}

Table 3 presents the demographics of the sample split by group. In both groups, the majority of the respondents are on the younger age ranges covering 18-34 years old individuals. Over 42 years-old respondents are a minority, indicating that both groups are of quite young people.

Regarding gender, the vast majority is of men in both groups. Most of the respondents also have at least a bachelor's degree, with a sizeable portion holding graduate titles, showing that the respondents are academically qualified. Apparently, though, foreigners are about 2 times more likely to hold an advanced masters or doctors' degree than Brazilians, while Brazilians are much more likely to hold other types of graduate titles (specialization). This may stem from the fact that in many countries, especially from the European Union, the Bologna Process leads to 3-4 years bachelor's degrees and to 1-2 years master's degrees, while in Brazil a bachelor's degree typically requires 4-5 years of study, and a master's, typically 2 . 
Table 3: Sample demographics

\begin{tabular}{|c|c|c|c|}
\hline Variable & Class & $\begin{array}{c}\text { Brazilians } \\
(\%)\end{array}$ & $\begin{array}{c}\text { Foreigners } \\
(\%)\end{array}$ \\
\hline \multirow{5}{*}{ Age } & $18-24$ & 24.61 & 23.07 \\
\hline & $25-28$ & 32.30 & 26.92 \\
\hline & $29-34$ & 23.07 & 24.61 \\
\hline & $35-42$ & 12.93 & 17.69 \\
\hline & over 42 & 7.07 & 7.69 \\
\hline \multirow{2}{*}{ Gender } & Female & 8.61 & 10.76 \\
\hline & Male & 91.38 & 89.23 \\
\hline \multirow{4}{*}{ Education } & High school & 3.07 & 6.15 \\
\hline & Bachelor & 63.07 & 54.61 \\
\hline & Other graduate studies & 18.46 & 4.61 \\
\hline & Master/Doctorate/PhD & 15.38 & 34.61 \\
\hline \multirow{9}{*}{ Startup market } & Mobile app & 12.92 & 6.15 \\
\hline & E-commerce & 9.53 & 4.61 \\
\hline & Education & 6.46 & 3.84 \\
\hline & Games & 3.38 & 1.53 \\
\hline & Artificial intelligence (robotics) & 1.84 & 0.76 \\
\hline & Sustainable products & 2.76 & 0.76 \\
\hline & Health & 5.53 & 6.92 \\
\hline & Services & 30.46 & 20.76 \\
\hline & Others & 27.07 & 33.84 \\
\hline \multirow{3}{*}{$\begin{array}{l}\text { Working } \\
\text { experience }\end{array}$} & I already have startup experience & 36 & 47.69 \\
\hline & $\begin{array}{l}\text { I never had startup experience but I had worked } \\
\text { in companies }\end{array}$ & 52 & 39.23 \\
\hline & I don't have experience & 12 & 15.38 \\
\hline $\begin{array}{l}\text { Total respondents } \\
\text { (n) }\end{array}$ & & 325 & 130 \\
\hline
\end{tabular}

Brazilians operate mostly in the Services industry. In turn, most foreigners indicate they operate in "Other" industries. In both cases, only a minority operates within the AI industry, possibly due to the highly technical nature of the field. Most of the respondents in both groups have some kind of work experience. In the Brazilian case, most of the respondents have previous experience in a non-startup firm, whereas almost half of the foreigners report previous startup experience. Overall, groups do not exhibit marked differences in their demographics, in line with previous literature (Stewart et al., 2008). The sample exhibits differences when compared to the demographics of other international studies, in particular age and education, but they are attributable to differences in target entrepreneurship areas (Carter et al., 2003; Chen and Elston, 2013; Cowling, 2000).

\section{Descriptive analysis}

The mean score provides a ranking order of most to least important reason for each group. In turn, a low standard deviation indicates clusters in answers. Table 4Error! Reference source not found. shows the top five reasons for each group. The top-ranked reason, market opportunity, corroborate previous results from Bayon et al. (2015) and Hayton and Cholakova (2012). It also supports the argument that the entrepreneur needs to see an opportunity that will give birth to its startup (Saemundsson and Holmén, 2011).

The same reasons figure in positions two through four for both groups, although positions three and four switch between groups. All of them belong to the self-realization factor, showing that both groups are seeking for learning and personal growth, new challenges and self-accomplishment. This is in line with Alstete (2002), who finds increased satisfaction as a reason among New York prospective entrepreneurs to open a business. 
Finally, groups differ on the fifth reason, Brazilians stating many product ideas, while foreigners highlight the importance of freedom for work methods. Foreigners desiring more freedom corroborate results from Alstete (2002), Dawson and Henley (2012) and Kirkley (2016), who find independence and greater control over destiny as top reasons for starting a new business in the New Zealand, UK, and US, respectively. Kiwis also cite creativity as a top reason (Kirkley, 2016), in line with Brazilians saying that many products ideas are an important reason to open a business.

Table 4: Top-ranked reasons

\begin{tabular}{llll}
\hline BRAZILIANS & & FOREIGNERS & \\
\hline Reason & Mean & Reason & Mean \\
\hline Market opportunity (INOV4) & 4.34 & Market opportunity (INOV4) & 4.28 \\
Learn as a person (AR3) & 4.21 & Learn as a person (AR3) & 4.21 \\
New challenges (AR2) & 4.20 & Self-realization (AR1) & 4.18 \\
Self-realization (AR1) & 4.16 & New challenges (AR2) & 4.15 \\
Many products ideas (INOV3) & 3.84 & Freedom for work methods (IND2) & 4.00 \\
\hline
\end{tabular}

Notes: Table show mean scores, extracted from a 5-point Likert scale, for top-ranked reasons for each group. The value between parentheses indicate to which factor each reason belongs. INOV is innovation, AR is self-realization, and IND is independence. $\mathrm{N}=325$ for Brazilians, and $\mathrm{N}=130$ for foreigners. Full results are in Table 9 in the Appendix.

Low variances indicate possible clusters or homogeneity in scores. Table 5 shows the five reasons with the least dispersion. Almost all exhibit standard deviations close to one, showing lack of homogeneity. Most of the reasons are common between the two groups, with family tradition appearing only in the Brazilian sample and self-realization showing up in the foreign sample.

Table 5: Lowest standard deviations

\begin{tabular}{llll}
\hline BRAZILIANS & & FOREIGNERS & \\
\hline Reason & Std. Dev. & Reason & Std. Dev. \\
\hline Friend's respect (REC3) & 0.6306 & Friend's respect (REC3) & 0.9617 \\
Family tradition (PA2) & 0.8932 & Market opportunity (INOV4) & 0.9806 \\
Market opportunity (INOV4) & 0.9309 & Self-realization (AR1) & 0.9920 \\
Learn as a person (AR3) & 1.0067 & New challenges (AR2) & 1.0074 \\
New challenges (AR2) & 1.0153 & Learn as a person (AR3) & 1.0395 \\
\hline
\end{tabular}

Notes: Table shows the lowest standard deviations from scores, extracted from a 5-point Likert scale, for each group. The value between parentheses indicate to which factor each reason belongs. REC is recognition, PA is role, INOV is innovation, and AR is self-realization. $\mathrm{N}=325$ for Brazilians, and $\mathrm{N}=130$ for foreigners. Full results are in Table 9 in the Appendix.

Table 6 shows the top five standard deviations for each group. Among Brazilians, the highest standard deviation was for flexibility, i.e., having more flexibility in personal life in relation to work. About $1 / 4$ of Brazilians (26.15\%) partially or strongly disagree, while about half $(50.76 \%)$ partially or strongly agree. These proportions indicate that Brazilian entrepreneurs do not agree that having flexibility in personal life in relation to work is a major reason to open a startup, although a slight majority do.

The second highest deviation for Brazilians relates to having the power to influence a company, a standard deviation of 1.36 , due to $30.15 \%$ partially or strongly disagreeing and $43.69 \%$ partially or strongly agreeing. This lack of consensus may relate to the fact that startups are small and nascent businesses that have been in the market for a short span of time (Xavier and Cancellier, 2008), so the power to influence of the founder or owner is contingent on its size.

Building wealth ranks third in deviation among Brazilians. About a third $(30.69 \%)$ partially or strongly disagree and another third $(36.31 \%)$ partially or strongly agree, showing a divide within Brazilians. The uncertainty startups face, and consequently their high failure rate, may drive this lack of consensus (Dubini, 1989; Francis and Bessant, 2005). The same rationale can account for the fourth and fifth largest deviations.

Among foreigners, financial security shows the top deviation. Within this group, $43.85 \%$ partially or strongly disagree and $34.62 \%$ partially or strongly agree. Again, high variance in results and high mortality rates can account for this (Dubini, 1989; Francis and Bessant, 2005). 
Creating and selling new products rank second in deviation. In this case, $42.31 \%$ partially or strongly disagree and $39.25 \%$ partially or strongly agree. Within this group, most of the respondents are in the Services, thus not creating new products. It may also explain the high variance for many product ideas.

Building capital for heirs show the third largest deviation. About a third (64.61\%) partially or strongly disagrees and a fifth $(20 \%)$ partially or strongly agree. High failure rates can also explain this high rate of disagreement (Dubini, 1989; Francis and Bessant, 2005).

Table 6: Highest standard deviations

\begin{tabular}{lclc}
\hline BRAZILIANS & \multicolumn{2}{c}{ FOREIGNERS } & Std. Dev. \\
\hline Reason & Std. Dev. Reason & 1.4633 \\
\hline Flexibility (IND1) & 1.3846 & Financial security (FIN4) & 1.4169 \\
To have power to influence a company (AR5) & 1.3622 & Create and sell new products (INOV1) & 1.3854 \\
Build wealth (FIN5) & 1.3565 & For children to inherit (PA1) & 1.3503 \\
Financial security (FIN4) & 1.3100 & Many products ideas (INOV3) & 1.3543 \\
Society's recognition (REC2) & 1.3055 & Flexibility (IND1) & 1.3443 \\
\hline
\end{tabular}

Notes: Table shows the highest standard deviations from scores, extracted from a 5-point Likert scale, for each group. The value between parentheses indicate to which factor each reason belongs. IND is independence, AR is selfrealization, FIN is financial, REC is recognition, PA is role, and INOV is innovation. N=325 for Brazilians, and $\mathrm{N}=130$ for foreigners. Full results are in Table 9 in the Appendix.

Overall, results show that both Brazilian and foreign entrepreneurs have mostly similar reasons to open their own startups, in line with Stewart et al. (2008) study with American and Indian entrepreneurs. These common reasons arise even among people from different countries and settings (Hofstede, 1984; Mueller and Thomas, 2001). However, entrepreneurs weight reasons differently, which the paper explores next.

\section{Relative differences between Brazilians and foreigners}

Now the focus is the analysis of how perceptions differ between Brazilian and foreign entrepreneurs. Difference in means tests indicate that nine out of the 22 variables have a significant difference at a $5 \%$ alpha. Two factors presented no differences between groups, indicating that entrepreneurs both in Brazil and abroad value them equally: self-realization and roles. Table 7 details the results.

Both differences in the Financial factor are negative, meaning that Brazilians rank financial security and wealth building as less important reasons for opening startups than foreigners. The same goes for the differences in the Independence factor, Brazilians ranking flexibility and freedom to implement work methods as less important than their foreign counterparts.

The sign changes in the Innovation factor. Brazilians hold the variables under this factor more dearly than foreigners. For Brazilians, creating and selling new products, following technological innovation, and having many products ideas are relatively more important reasons to open their startups.

In the Recognition factor, signs are inconsistent. Brazilians value more the importance in the market and society, whereas foreigners give relatively more importance to friends' respect. 
Table 7: Differences in means between Brazilians and Foreigners

\begin{tabular}{|c|c|c|c|c|c|c|c|}
\hline Variables & $\begin{array}{l}\text { Diff in } \\
\text { Means }\end{array}$ & $\begin{array}{c}\text { Equal } \\
\text { variances }\end{array}$ & $\begin{array}{l}\text { Std. } \\
\text { Error }\end{array}$ & $\mathbf{t}$ & p-value & Lower & Upper \\
\hline \multirow{2}{*}{$\begin{array}{l}\text { Financial } \\
\text { (FIN4) }\end{array}$} & \multirow{2}{*}{-0.55538} & Yes & 0.1407 & -3.95 & 0.0000 & -0.8318 & -0.2790 \\
\hline & & No & 0.1475 & -3.77 & 0.0000 & -0.8461 & -0.2647 \\
\hline \multirow{2}{*}{ Build wealth (FIN5) } & \multirow{2}{*}{-0.38154} & Yes & 0.1391 & -2.74 & 0.0060 & -0.6549 & -0.1082 \\
\hline & & No & 0.1365 & -2.79 & 0.0060 & -0.6505 & -0.1126 \\
\hline \multirow{2}{*}{ Flexibility (IND1) } & \multirow{2}{*}{-0.29846} & Yes & 0.1425 & -2.09 & 0.0370 & -0.5785 & -0.0184 \\
\hline & & No & 0.1407 & -2.12 & 0.0350 & -0.5756 & -0.0213 \\
\hline \multirow{2}{*}{$\begin{array}{l}\text { Freedom for work } \\
\text { methods (IND2) }\end{array}$} & \multirow{2}{*}{-0.36308} & Yes & 0.1244 & -2.92 & 0.0040 & -0.6076 & -0.1186 \\
\hline & & No & 0.1209 & -3.00 & 0.0030 & -0.6011 & -0.1251 \\
\hline \multirow{2}{*}{$\begin{array}{l}\text { Create and sell new } \\
\text { products (INOV1) }\end{array}$} & \multirow{2}{*}{0.72154} & Yes & 0.1342 & 5.38 & 0.0000 & 0.4578 & 0.9852 \\
\hline & & No & 0.1421 & 5.08 & 0.0000 & 0.4415 & 1.0015 \\
\hline \multirow{2}{*}{$\begin{array}{l}\text { Follow technological } \\
\text { Innovation (INOV2) }\end{array}$} & \multirow{2}{*}{0.61538} & Yes & 0.1362 & 4.52 & 0.0000 & 0.3478 & 0.8830 \\
\hline & & No & 0.1382 & 4.45 & 0.0000 & 0.3431 & 0.8876 \\
\hline \multirow{2}{*}{$\begin{array}{l}\text { Many products ideas } \\
\text { (INOV3) }\end{array}$} & \multirow{2}{*}{0.44308} & Yes & 0.1307 & 3.39 & 0.0010 & 0.1863 & 0.6999 \\
\hline & & No & 0.1364 & 3.25 & 0.0010 & 0.1742 & 0.7120 \\
\hline \multirow{2}{*}{$\begin{array}{l}\text { Importance in market - } \\
\text { society (REC1) }\end{array}$} & \multirow{2}{*}{0.24923} & Yes & 0.1238 & 2.01 & 0.0450 & 0.0060 & 0.4924 \\
\hline & & No & 0.1193 & 2.09 & 0.0380 & 0.0143 & 0.4842 \\
\hline \multirow{2}{*}{$\begin{array}{l}\text { Friend's } \\
\text { (REC3) }\end{array}$} & \multirow{2}{*}{-0.39538} & Yes & 0.0768 & -5.15 & 0.0000 & -0.5463 & -0.2444 \\
\hline & & No & 0.0913 & -4.33 & 0.0000 & -0.5756 & -0.2152 \\
\hline
\end{tabular}

Notes: This table presents only differences significant at 5\%. Diff in Means is Mean(Brazilians) - Mean(Foreigners). Equal variances states if the test assumes equal variances or not. Std. Error is the standard error of the difference, $\mathrm{t}$ is the $\mathrm{t}$ statistic, $\mathrm{p}$-value is the significance of the test, Lower is the lower limit of the difference in a $95 \%$ confidence interval, Upper is the upper limit of the difference in a 95\% confidence interval. FIN is financial, IND is independence, INOV in innovation, and REC is recognition.

Reasons that foreigners hold more dearly than Brazilians are in line with existing literature. Chen and Elston (2013) state the need to achieve financial security as an important reason for opening restaurants in China. Alstete (2002), Carsrud and Brännback (2011), Dawson and Henley (2012), Dubini (1989) and Friedman and Aziz (2012) find that one of the main drivers for entrepreneurs' motivations is building wealth, which is connected the vision of entrepreneurship as an attractive career that leads to high status and money. In sum, foreigners give more value to external reasons, like the idea of achieving a financial goal or a life style connected to money and status. In turn, Brazilian entrepreneurs are more concerned about internal reasons, connected to achieving an objective or a mean for themselves (Alstete, 2002; Carsrud and Brännback, 2011; Chen and Elston, 2013; Dawson and Henley, 2012; Dubini, 1989; Friedman and Aziz, 2012).

\section{Regression analysis}

While the preceding descriptive analysis provides an overview of how Brazilians and Foreigners differ, it does not account for simultaneously changing values. Next is a Logit model that estimates the factors which are significant in discriminating a Brazilian from a foreigner. This technique was chosen because the dependent variable has only two groups, thus being fit for a Logit model. Moreover, as Hair et al. (2003) point, logistic regression is more robust than discriminant analysis, which possesses very strict assumptions, while providing the same insights of a two-group discriminant analysis. Table 8Error! Reference source not found. presents the results, both the level and the marginal coefficients. The importance of the marginal effect is to go a step further from statistical significance to the practical significance of the findings, and is especially useful for nonlinear models like Logit (Williams, 2012). 
Table 8: Discriminating Brazilians from Foreigners

\begin{tabular}{|c|c|c|}
\hline Dep. Variable: Brazilian & Logit & Marginal effects \\
\hline \multicolumn{3}{|l|}{ Main effects: } \\
\hline \multirow[t]{2}{*}{ Self-realization } & 0.0804 & 0.0126 \\
\hline & $(0.4389)$ & $(0.4392)$ \\
\hline \multirow[t]{2}{*}{ Financial success } & $-0.2633^{*}$ & $-0.0414 *$ \\
\hline & $(-1.7642)$ & $(-1.7803)$ \\
\hline \multirow[t]{2}{*}{ Independence } & $-0.4502 * * *$ & $-0.0708 * * *$ \\
\hline & $(-3.3487)$ & $(-3.5080)$ \\
\hline \multirow[t]{2}{*}{ Innovation } & $0.9092 * * *$ & $0.1430 * * *$ \\
\hline & $(5.8583)$ & $(6.7911)$ \\
\hline \multirow[t]{2}{*}{ Roles } & $-0.2937 *$ & $-0.0462 *$ \\
\hline & $(-1.6924)$ & $(-1.7087)$ \\
\hline \multirow[t]{2}{*}{ Recognition } & -0.1416 & -0.0223 \\
\hline & $(-0.8249)$ & $(-0.8291)$ \\
\hline \multicolumn{3}{|l|}{ Controls: } \\
\hline \multirow[t]{2}{*}{ Gender } & 0.0873 & 0.0137 \\
\hline & $(0.2296)$ & $(0.2296)$ \\
\hline \multicolumn{3}{|l|}{ Age range: } \\
\hline \multirow[t]{2}{*}{$25-28$} & -0.0253 & -0.0038 \\
\hline & $(-0.0705)$ & $(-0.0706)$ \\
\hline \multirow[t]{2}{*}{$29-34$} & -0.2717 & -0.0428 \\
\hline & $(-0.7220)$ & $(-0.7266)$ \\
\hline \multirow[t]{2}{*}{$25-42$} & -0.3338 & -0.0530 \\
\hline & $(-0.7993)$ & $(-0.7967)$ \\
\hline \multirow[t]{2}{*}{ Over 42} & -0.3391 & -0.0539 \\
\hline & $(-0.6673)$ & $(-0.6577)$ \\
\hline \multicolumn{3}{|l|}{ Education: } \\
\hline \multirow[t]{2}{*}{ Bachelor } & $1.1986^{*}$ & 0.2236 \\
\hline & $(1.7211)$ & $(1.6092)$ \\
\hline \multirow[t]{2}{*}{ Other graduate } & $2.6083 * * *$ & $0.3899 * * *$ \\
\hline & $(2.9912)$ & $(2.7225)$ \\
\hline \multirow[t]{2}{*}{$\mathrm{MSc} / \mathrm{PhD}$} & 0.1798 & 0.0362 \\
\hline & $(0.2496)$ & $(0.2491)$ \\
\hline \multicolumn{3}{|l|}{ Startup type: } \\
\hline \multirow[t]{2}{*}{ E-commerce } & 0.0018 & 0.0003 \\
\hline & $(0.0038)$ & $(0.0038)$ \\
\hline \multirow[t]{2}{*}{ Education } & -0.5456 & -0.0938 \\
\hline & $(-1.0451)$ & $(-1.0398)$ \\
\hline \multirow[t]{2}{*}{ Games } & 0.2862 & 0.0440 \\
\hline & $(0.3455)$ & $(0.3559)$ \\
\hline \multirow[t]{2}{*}{ AI/Robotics } & 1.1407 & 0.1495 \\
\hline & $(1.0123)$ & $(1.2405)$ \\
\hline \multirow[t]{2}{*}{ Sustainable prd } & 1.6440 & $0.1932 * *$ \\
\hline & $(1.5126)$ & $(2.0348)$ \\
\hline Health & -0.3952 & -0.0668 \\
\hline
\end{tabular}




\begin{tabular}{lcc}
\hline Dep. Variable: Brazilian & Logit & Marginal effects \\
\hline \multirow{2}{*}{ Services } & $(-0.6486)$ & $(-0.6383)$ \\
& 0.4344 & 0.0652 \\
Others & $(1.0080)$ & $(0.9881)$ \\
& -0.2631 & -0.0438 \\
Experience level: & $(-0.6392)$ & $(-0.6487)$ \\
Previous company exp (no startup) & $0.7687^{* * *}$ & $0.1225^{* * *}$ \\
& $(2.8069)$ & $(2.8414)$ \\
Previous startup exp & 0.2876 & 0.0489 \\
& $(0.8295)$ & $(0.8422)$ \\
\hline Pseudo R-squared & 0.1994 & 0.1994 \\
Observations & 455 & 455 \\
\hline
\end{tabular}

Notes: This table presents level and marginal effects of a Logit model with robust standard errors that associates entrepreneurs' characteristics with the likelihood of being Brazilian. The dependent variable is Brazilian, a dummy equal to 1 if the entrepreneur is Brazilian. The main independent variables are the factors Selfrealization, Financial success, Independence, Innovation, Roles and Recognition. Each one of the factors is the arithmetic mean of the answers provided by the entrepreneur within that factor. The control variables are Gender, a dummy equal to 1 for male entrepreneurs, Age range dummies, with 18-24 being the base class, Education dummies, with High school being the base class, Startup type dummies, with Mobile being the base class, and Experience level dummies, with No Experience being the base class. Marginal effects are the average partial effects. Values in parentheses are the t stats; *,** and *** mean statistical significance at $10 \%, 5 \%$ and $1 \%$, respectively.

In general, the regression model corroborates previous patterns from the descriptive analysis. The financial success factor is negatively related to the entrepreneur being a Brazilian. A drop of one point in this factor increases the likelihood of being a Brazilian entrepreneur in 4.1 percentage points (p.p.). The same is valid for the independence factor, with less one point translating into an increase of more than 7 p.p. in the likelihood. The effect of the innovation factor is positive, with an additional point being associated with a 14 p.p. increase in the chance of being Brazilian.

The effect of the roles factor did not appear in the descriptive analysis. The Logit estimate indicates that Brazilians are associated with a lower score for roles, with less one point translating into a 4.6 p.p. increase in the likelihood of being Brazilian. In some sense this result differs from Miralles et al. (2015), who find that social norm, akin to roles, is positively linked to entrepreneurial intention in a sample of Catalonians (Northeastern Spain). Predictably, the effect of the recognition factor is not significant, since the descriptive analysis indicated inconsistent relative ratings within this factor.

As for the controls, having a non-Msc/PhD graduate diploma, being a sustainable products entrepreneurs and having previous company experience (except startups) are related with a higher likelihood of the entrepreneur being Brazilian. Comparatively, we find no difference regarding gender, although Tsai et al. (2016) find that gender is an important determinant of entrepreneurial intention in a sample of Taiwanese and Chinese people. This signals that there may be few cross-country differences regarding the effect of gender, reinforcing the advice of Bjørnskov and Foss (2016).

\section{Discussion}

Results point that from the top five ranked reasons in each group, three are related to self-realization. This corroborates Carter et al. (2003), who find that the self-realization factor is the most important in determining entrepreneurial behavior. However, Brazilians seem to value innovation as the second-most 
important factor, differing from Carter et al. (2003), who list innovation as only the fourth most important for Americans.

Segal et al. (2005) find that a measure of net desirability to become self-employed (NDSE) is significant in explaining the level of self-employment intentions among American undergraduate students. NDSE is a composite measure that takes into account the difference between the options of self-employment and working for others along two financial dimensions (income potential and financial security), one selfrealization dimension (need for achievement), and two independence dimensions (independence and escape from corporate bureaucracy). It contrasts with the Brazilian prevalence for self-realization, a minor component of NDSE, and factors outside NDSE, like innovation.

According to Kirkley (2016), New Zealanders usually associate entrepreneurial behavior with independence and choosing own goals, which can be classified into the independence factor, and ambition and daring, related to the self-realization factor. These interviewees show alignment with Brazilians, citing self-realization as important determinants of entrepreneurship, and with Americans, given the importance of financial dimensions for them.

Using a large sample from an UK survey, Dawson and Henley (2012) show that British entrepreneurs are mostly concerned with independence. They also cite finance as an important factor, mostly aligned with findings in the US and differing from Brazilian results.

All in all, the results of this research highlight how different contexts can lead to different reasons to enterprise. This signals the importance of properly identifying local characteristics to be able to customize entrepreneurship initiatives and policies to maximize efficiency.

\section{Conclusion}

This research identifies reasons for Brazilian and foreign entrepreneurs to open technological startups, and makes a comparative analysis between the two groups. It contributes to the understanding of the entrepreneurship phenomenon in an important emerging market, a field considered key for healthy economies (Barba-Sanchez and Atienza-Sahuquillo, 2011; Beckman et al., 2012; Bruyat and Julien, 2001; Dvir et al.,2010; Feeser and Willard ,1989; Grimaldi and Grandi, 2005; Hansen et al., 2011; Mueller and Thomas, 2001; Saemundsson and Holmén, 2011; Shane, 1996; Stuetzer et al.,2012).

Top ranked reasons are similar between groups. Brazilians cite market opportunity, learning as a person, new challenges, self-realization and many products ideas as their main reasons for opening a startup. Foreigners rank the first four, plus freedom to implement work methods, as their top reasons. This result highlights the importance of the Start Up Brasil program, created by the federal government, and also the launch of Sebrae Up program. These programs aim at stimulating entrepreneurs to open their startup, by supporting them in exploiting market opportunities, creating their products and conducting market research, thus mitigating their failure rate (Dubini, 1989; Francis and Bessant, 2005; Ministério da Ciência, Tecnologia e Inovação - MCTI, 2016; Sebrae, 2014).

The groups also exhibit different comparative values for nine of the variables. Brazilians give more importance to selling products that they invented, to the market innovations, to new products ideas and to the startup importance for society and market. Foreigners favor financial security, building wealth, flexibility, freedom to implement work methods and friends' respect. The Logit model corroborates this findings, giving robustness to the descriptive results.

Limitations of this study include the relatively low number of respondents, and the non-probabilistic sample, restricting the generalizability of the results. Budget restraints only allowed for the application of the questionnaire for foreigners through the internet, partly explaining their lower participation. 
Furthermore, foreigners come from more than 20 different countries, but none had enough respondents to be analyzed separately against Brazil.

This paper's results deepen the understanding of the reasons for entrepreneurs to open technological startups, producing evidence to better assist them and filling a gap in comparative studies in entrepreneurship (Krueger and Brazeal, 1994; Mueller and Thomas, 2001). Findings extend Carter et al., (2003) by studying a large emerging market and comparing it with foreigners. It also provides government and society with a diagnostic that can help stimulate and support entrepreneurs, leading to an increase in the entrepreneurial activity (Birley, 1986; Bosma et al., 2012; Mueller and Thomas, 2001; Shane, 1996; Van den Ven et al., 1984). Outside support may be especially important for Brazilian entrepreneurs, who rank learning as a person as a top reason.

One future improvement is on the nature of the sample, by broadening it and getting enough respondents, at least from the largest countries, to generate meaningful comparisons between different countries and Brazil. Another avenue for research is comparing reasons between technological and non-technological startups. Finally, understanding why entrepreneurs close their startups may lead to better support policies and to an increase in survivorship rates. 


\section{References}

Ahmad, N. and Seymour, R. (2008), Defining Entrepreneurial Activity: Definitions Supporting Frameworks for Data Collection, OECD Statistics Working Papers, 2008/01, OECD Publishing, Paris, doi: $10.1787 / 243164686763$.

Alstete, J. W. (2002), On becoming an entrepreneur: an evolving typology, International Journal of Entrepreneurial Behavior \& Research, 8(4), pp. 222-234.

Associação Brasileira de Startups. O que é startup? Available at: http://www.abstartups.com.br/ (Accessed 24 March 2013).

Autio, E. H., Keeley, R., Klofsten, M. G. C., Parker, G. and Hay, M. (2001), Entrepreneurial intent among students in Scandinavia and in the USA, Enterprise and Innovation Management Studies, 2(2), pp. 145160.

Baglieri, D. and Lorenzoni, G. (2014), Closing the distance between academia and market: experimentation and user entrepreneurial processes, The Journal of Technology Transfer, 39, pp. 52-74.

Barba-Sanchez, V. and Atienza-Sahuquillo, C. (2011), Reasons to create a new venture: A determinant of entrepreneurial profiles, African Journal of Business Management, 5(28), pp. 11497-11504.

Bayon, M. C., Vaillant, Y. and Lafuente, E. (2015), Initiating nascent entrepreneurial activities: The relative role of perceived and actual entrepreneurial ability, International Journal of Entrepreneurial Behavior \& Research, 21(1), pp.27-49.

Beckman, C., Eisenhardt, K., Kotha, S., Meyer, A. and Rajagopalan, N. (2012), Technology entrepreneurship.Strat, Journal of Entrepreneurship, doi: 10.1002/sej.1134

Birley, S. (1986), The role of new firms: Births, deaths and job generation, Strategic Management Journal, 7(4), pp. 361-376.

Bjørnskov, C. and Foss, N.J. (2016) Institutions, Entrepreneurship, and Economic Growth: What Do We Know and What Do We Still Need to Know? The Academy of Management Perspectives, 30(3), 292-315, doi: 10.5465/amp.2015.0135.

Block, J. H., and Landgraf, A. (2016), Transition from part-time entrepreneurship to full-time entrepreneurship: the role of financial and non-financial motives, International Entrepreneurship and Management Journal, 12, pp. 259-282.

Bosma, N., Hessels, J., Schutjens, V., Praag, M. V., and Verheul, I. (2012), Entrepreneurship and role models, Journal of Economic Psychology, 33(2), pp. 410-424.

Bruyat, C. and Julien, P. A. (2001), Defining the field of research in entrepreneurship, Journal of Business Venturing, 16(2), pp. 165-180.

Buijs, J. (2008), Action planning for new product development projects, Creativity and Innovation Management, 17(4), pp. 319-333.

Carayannis, E. G., Popescu, D., Sipp, C. and Stewart, M. (2006), Technological learning for entrepreneurial development (TL4ED) in the knowledge economy (KE): case studies and lessons learned, Technovation, 26(4), pp. 419-443.

Carsrud, A. and Brännback, M. (2011), Entrepreneurial motivations: what do we still need to know?, Journal of Small Business Management, 49(1), pp. 9-26.

Carter, N. M., Gartner, W. B. and Reynolds, P. D. (1996), Exploring start-up event sequences, Journal of Business Venturing, 11(3), pp. 151-166.

Carter, N. M., Gartner, W. B., Shaver, K. G. and Gatewood, E. J. (2003), The career reasons of nascent entrepreneurs, Journal of Business Venturing, 18(1), pp. 13-39.

Chen, S. C. and Elston, J. A. (2013), Entrepreneurial motives and characteristics: An analysis of small restaurant owners, International Journal of Hospitality Management, 35, pp. 294-305. 
Collins, C. J., Hanges, P.J., and Locke E. A. (2004). The Relationship of Achievement Motivation to Entrepreneurial Behavior: A Meta-Analysis. Human Performance, 17(1) 95-117, doi: 10.1207/S15327043HUP1701_5.

Cowling, M. (2000), Are entrepreneurs different across countries?, Applied Economics Letters, 7(12), pp. 785-789.

Dawson, C. and Henley, A. (2012). 'Push' versus 'pull' entrepreneurship: an ambiguous distinction?, International Journal of Entrepreneurial Behavior \& Research, 18(6), pp.697-719.

Del Junco, J. G. and Brás-dos-Santos, J. M. (2009), How different are the entrepreneurs in the European Union internal market?-An exploratory cross-cultural analysis of German, Italian and Spanish entrepreneurs, Journal of International Entrepreneurship, 7(2), pp. 135-162.

Deshpandé, R., Grinstein, A., Kim, S.H. and Ofek, E., (2013), Achievement motivation, strategic orientations and business performance in entrepreneurial firms: How different are Japanese and American founders?, International Marketing Review, 30(3), pp.231-252, doi: 10.1108/02651331311321981.

Dubini, P. (1989), The influence of motivations and environment on business start-ups: Some hints for public policies, Journal of Business Venturing, 4(1), pp. 11-26.

Dvir, D., Sadeh, A. and Malach-Pines, A. (2010), The fit between entrepreneurs' personalities and the profile of the ventures they manage and business success: An exploratory study, The Journal of High Technology Management Research, 21(1), pp. 43-51.

Estay, C., Durrieu, F. and Akhter, M. (2013). Entrepreneurship: From motivation to start-up, Journal of International Entrepreneurship, 11(3), pp. 243-267, doi: 10.1007/s10843-013-0109-X.

Feeser, H. R., and Willard, G. E. (1989), Incubators and performance: a comparison of high-and low-growth high-tech firms, Journal of Business Venturing, 4(6), pp. 429-442.

Ferreira, J. J. M., Ferreira, F. A. F., Fernandes, C. I. M. A. S., Jalali, M. S., Raposo, M. L., Marques, C. S. (2016). What do we [not] know about technology entrepreneurship research? International Entrepreneurship and Management Journal, 12(3), 713-733, doi:10.1007/s11365-015-0359-2.

Ferreira. J. J. M., Raposo, M. L., Rodrigues, R. G., Dinis, A., do Paço, A., (2012). A model of entrepreneurial intention: An application of the psychological and behavioral approaches, Journal of Small Business and Enterprise Development, 19(3), pp.424-440, doi: 10.1108/14626001211250144.

Francis, D. and Bessant, J. (2005), Targeting innovation and implications for capability development, Technovation, 25(3), pp. 171-183.

Friedman, B. A. and Aziz, N. (2012), Turkey and the United States: Entrepreneurship Activity, Motives, Aspirations, and Perceptions, International Journal of Business and Social Science, 3(3), pp. 96-107.

Gartner, W. B. (1990), What are we talking about when we talk about entrepreneurship?, Journal of Business Venturing, 5(1), pp. 15-28.

Giuri, P., Mariani, M., Brusoni, S., Crespi, G., Francoz, D., Gambardella, A., et al. (2007). Inventors and invention processes in Europe: results from the PatVal-EU survey, Research Policy, 36(8), 1107-1127, doi: 10.1016/j.respol.2007.07.008.

Grimaldi, R. and Grandi, A. (2005), Business incubators and new venture creation: an assessment of incubating models, Technovation, 25(2), pp. 111-121.

Gupta, V. and Fernandez, C. (2009), Cross-Cultural Similarities and Differences in Characteristics Attributed to Entrepreneurs A Three-Nation Study, Journal of Leadership \& Organizational Studies, 15(3), pp. 304-318.

Hair, J. F., Babin, B. J., Money, A. H. and Samouel, P. (2003), Essentials of Business Research Methods, Wiley, New York, NY.

Hansen, J. D., Deitz, G. D., Tokman, M., Marino, L. D. and Weaver, K. M. (2011), Cross-national invariance of the entrepreneurial orientation scale, Journal of Business Venturing, 26(1), pp. 61-78.

Hayton, J. C. and Cholakova, M. (2012), The role of affect in the creation and intentional pursuit of entrepreneurial ideas, Entrepreneurship Theory and Practice, 36(1), pp. 41-68. 
Hofstede, G. (1984), Cultural dimensions in management and planning, Asia Pacific journal of management, 1(2), pp. 81-99.

Jayawarna, D., Rouse, J. and Kitching, J. (2013) Entrepreneur motivations and life course, International Small Business Journal, 31(1), pp. 34-56, doi: 10.1177/0266242611401444.

Jaskiewicz, P., Combs, J. G. and Rau, S.B. (2015) Entrepreneurial legacy: Toward a theory of how some family firms nurture transgenerational entrepreneurship, Journal of Business Venturing, 30(1), pp. 29-49, doi: 10.1016/j.jbusvent.2014.07.001.

Kirkley, W. W. (2016), Entrepreneurial behaviour: the role of values, International Journal of Entrepreneurial Behavior \& Research, 22(3), pp.290-328.

Koellinger, P., Minniti, M. and Schade, C. (2007), I think I can, I think I can: Overconfidence and entrepreneurial behavior, Journal of Economic Psychology, 28(4), pp. 502-527.

Krueger, N. F. and Brazeal, D. V. (1994), Entrepreneurial potential and potential entrepreneurs, Entrepreneurship Theory and Practice, 18, pp. 91-91.

Lages, M., Marques, C.S., Ferreira, J.J.M. et al. (2016), Intrapreneurship and firm entrepreneurial orientation: insights from the health care service industry, International Entrepreneurship and Management Journal, pp. 1-18, doi:10.1007/s11365-016-0428-1.

Liao, J., Welsch, H. and Tan, W. L. (2005), Venture gestation paths of nascent entrepreneurs: Exploring the temporal patterns, The Journal of High Technology Management Research, 16(1), pp. 1-22.

Lichtenstein, B. B., Carter, N. M., Dooley, K. J. and Gartner, W. B. (2007), Complexity dynamics of nascent entrepreneurship, Journal of Business Venturing, 22(2), pp. 236-261.

Marques, C.S.E., Ferreira, J.J.M., Ferreira, F.A.F. et al. (2013), Entrepreneurial orientation and motivation to start up a business: evidence from the health service industry, International Entrepreneurship and Management Journal, 9(1), pp. 77-94, doi:10.1007/s11365-012-0243-2.

Maslow, A. H. (1943). A theory of human motivation. Psychological Review. 50(4), 370-396.

MCTI - Ministério da Ciência, Tecnologia e Inovação, (2016). Estratégia Nacional de Ciência, Tecnologia e Inovação, available at: http://www.mcti.gov.br/documents/10179/1712401/Estrat\%C3\%A9gia+Nacional+de+Ci\%C3\%AAncia, \%20Tecnologia+e+Inova\%C3\%A7\%C3\%A3o+2016-2019/0cfb61e1-1b84-4323-b136-8c3a5f2a4bb7 (accessed 8 August 2016).

Miralles, F., Giones, F., and Riverola, C. (2016), Evaluating the impact of prior experience in entrepreneurial intention, International Entrepreneurship and Management Journal, 12, pp. 791-813.

Mueller, S. L., and Thomas, A. S. (2001), Culture and entrepreneurial potential: A nine country study of locus of control and innovativeness, Journal of business venturing, 16(1), pp. 51-75.

Oosterbeek, H., van Praag, M. and Ijsselstein, A. (2010), The impact of entrepreneurship education on entrepreneurship skills and motivation, European economic review, 54(3), pp. 442-454.

Park, J. S. (2005), Opportunity recognition and product innovation in entrepreneurial hi-tech start-ups: a new perspective and supporting case study, Technovation, 25(7), pp. 739-752.

Pillis, E. de and Reardon, K. K. (2007), The influence of personality traits and persuasive messages on entrepreneurial intention: a cross-cultural comparison, Career Development International, 12(4), pp. 382396.

Quatraro, F. and Vivarelli, M. (2015). Drivers of Entrepreneurship and Post-entry Performance of Newborn Firms in Developing Countries. World Bank Research Observer, 30(2), 277-305, doi: 10.1093/wbro/lku012.

Ramlow Campelli, M. G., Barbejat, P., Ramalho, M. E. and de Oliveira Moritz, G. (2011), Empreendedorismo no Brasil: situação e tendências, Revista de Ciências da Administração, 13(29), pp. $133-151$

Roure, J. B. and Keeley, R. H. (1990), Predictors of success in new technology based ventures, Journal of Business Venturing, 5(4), pp. 201-220. 
Saemundsson, R. J. and Holmén, M. (2011), Yes, now we can: Technological change and the exploitation of entrepreneurial opportunities, The Journal of High Technology Management Research, 22(2), pp. 102113.

Sahut, J. M. and Peris-Ortiz, M. (2014), Small business, innovation, and entrepreneurship, Small Business Economics, 42, pp. 663-668, doi:10.1007/s11187-013-9521-9.

SEBRAE. Sebrae Up, available at: http://www.sebrae.com.br/sites/PortalSebrae/ufs/es/cursos_eventos/Chamada-de-Projetos-\%E2\%80\%93Programa-de-Acelera\%C3\%A7\%C3\%A3o-SEBRAE-UP (Access 3 May 2014).

Segal, G., Borgia, D., Schoenfeld, J. (2005), The motivation to become an entrepreneur, International Journal of Entrepreneurial Behavior \& Research, 11(1), pp.42 - 57.

Shane, S. (1996), Explaining variation in rates of entrepreneurship in the United States: 1899-1988, Journal of Management, 22(5), pp. 747-781.

Shane , S. (2012), Reflections on the 2010 AMR Decade Award: Delivering on the Promise of Entrepreneurship As a Field of Research, Academy of Management Review, 37(1), pp. 10-20, doi:10.5465/amr.2011.0078.

Shaver, K. G., Gartner, W. B., Gatewood, E. J., Crosby, E. and Bakalarova, K. (2001), Attributions about entrepreneurship: A framework and process for analyzing reasons for starting a business, Entrepreneurship Theory and Practice, 26, pp. 5-32.

Shane, S., Kolvereid, L., Westhead, P. (1991). An exploratory examination of the reasons leading to new firm formation across country and gender. Journal of Business Venturing, 6(6), 431-446, doi: 10.1016/0883-9026(91)90029-D.

Simon, M., Houghton, S. M. and Aquino, K. (2000), Cognitive biases, risk perception, and venture formation: How individuals decide to start companies, Journal of business venturing, 15(2), pp. 113-134.

Song, M., Podoynitsyna, K., Van Der Bij, H. and Halman, J. I. (2008), Success Factors in New Ventures: A Meta-analysis, Journal of product innovation management, 25(1), pp. 7-27.

Stephan, U., Hart, M., Drews, C.-C. (2015), Understanding Motivations for Entrepreneurship A Review of Recent Research Evidence, Enterprise Research Centre and Aston Business School.

Stewart, W. H., May, R. C. and Kalia, A. (2008), Environmental perceptions and scanning in the United States and India: convergence in entrepreneurial information seeking? Entrepreneurship Theory and Practice, 32(1), pp. 83-106.

Stuetzer, M., Goethner, M. and Cantner, U. (2012), Do balanced skills help nascent entrepreneurs to make progress in the venture creation process? Economics Letters, 117(1), pp. 186-188.

Taormina, R. J., Lao, S. K. (2007). Measuring Chinese entrepreneurial motivation: personality and environmental influences. International Journal of Entrepreneurial Behavior \& Research, 13(4), 200 221, doi: 10.1108/13552550710759997.

Tsai, K-H., Chang, H-C., and Peng, C-Y. (2016), Refining the linkage between perceived capability and entrepreneurial intention: roles of perceived opportunity, fear of failure, and gender, International Entrepreneurship and Management Journal, pp. 1-19.

Van de Ven, A. H., Hudson, R. and Schroeder, D. M. (1984), Designing new business startups: Entrepreneurial, organizational, and ecological considerations, Journal of management, 10(1), pp. 87-108.

Vivarelli, M. (2013). Is entrepreneurship necessarily good? Microeconomic evidence from developed and developing countries. Industrial and Corporate Change, 22 (6), 1453-1495. doi: 10.1093/icc/dtt005.

West, G. P., Bamford, C. E. and Marsden, J. W. (2008), Contrasting entrepreneurial economic development in emerging Latin American economies: applications and extensions of resource-based theory, Entrepreneurship theory and practice, 32(1), pp. 15-36.

Williams, R. (2012), Using the margins command to estimate and interpret adjusted predictions and marginal effects, The Stata Journal, 12,(2), pp. 308-331.

Xavier, W. G. and Cancellier, E. L. P. L. (2008), Atividades de monitoramento em empresas de startup de base tecnológica na indústria do turismo, Análise, 19(2), pp. 107-119. 


\section{Appendix}

Table 9: Descriptive statistics - all 22 reasons

\begin{tabular}{|c|c|c|c|c|c|c|c|c|}
\hline \multirow{3}{*}{ SCORES } & \multicolumn{4}{|c|}{ BRAZILIANS } & \multicolumn{4}{|c|}{ FOREIGNERS } \\
\hline & \multicolumn{2}{|c|}{$\begin{array}{l}\text { Descriptive } \\
\text { Stats }\end{array}$} & \multicolumn{2}{|c|}{$\begin{array}{c}\text { Ranking } \\
\text { (highest=1) }\end{array}$} & \multicolumn{2}{|c|}{$\begin{array}{l}\text { Descriptive } \\
\text { Stats } \\
\end{array}$} & \multicolumn{2}{|c|}{\begin{tabular}{|c|} 
Ranking \\
(highest=1)
\end{tabular}} \\
\hline & Mean & $\begin{array}{l}\text { Std. } \\
\text { Dev. }\end{array}$ & Mean & Std. Dev. & Mean & $\begin{array}{l}\text { Std. } \\
\text { Dev. }\end{array}$ & Mean & Std. Dev. \\
\hline Self-realization (AR1) & 4.1600 & 1.0595 & 4 & 16 & 4.1769 & 0.9920 & 3 & 20 \\
\hline New challenges (AR2) & 4.2000 & 1.0153 & 3 & 18 & 4.1538 & 1.0074 & 4 & 19 \\
\hline Learn as a person (AR3) & 4.2123 & 1.0067 & 2 & 19 & 4.2077 & 1.0395 & 2 & 18 \\
\hline Lead and motivate others (AR4) & 3.6369 & 1.2634 & 9 & 9 & 3.5692 & 1.2385 & 9 & 12 \\
\hline $\begin{array}{l}\text { To have power to influence a } \\
\text { company (AR5) }\end{array}$ & 3.2062 & 1.3622 & 14 & 2 & 3.3692 & 1.2522 & 12 & 10 \\
\hline Financial success (FIN1) & 3.8031 & 1.0174 & 7 & 17 & 3.6308 & 1.2145 & 8 & 14 \\
\hline Financial independence (FIN2) & 3.5662 & 1.2520 & 11 & 10 & 3.7692 & 1.2423 & 6 & 11 \\
\hline Greater personal income (FIN3) & 3.2000 & 1.2693 & 15 & 8 & 3.3385 & 1.2172 & 13 & 13 \\
\hline Financial security (FIN4) & 2.2985 & 1.3100 & 19 & 4 & 2.8538 & 1.4633 & 16 & 1 \\
\hline Build wealth (FIN5) & 2.9262 & 1.3565 & 16 & 3 & 3.3077 & 1.2991 & 14 & 8 \\
\hline Flexibility (IND1) & 3.3631 & 1.3846 & 13 & 1 & 3.6615 & 1.3443 & 7 & 5 \\
\hline Freedom for work methods (IND2) & 3.6369 & 1.2212 & 9 & 13 & 4.0000 & 1.1412 & 5 & 15 \\
\hline $\begin{array}{l}\text { Create and sell new products } \\
\text { (INOV1) }\end{array}$ & 3.7138 & 1.2403 & 8 & 12 & 2.9923 & 1.4169 & 15 & 2 \\
\hline $\begin{array}{l}\text { Follow technological innovation } \\
\text { (INOV2) }\end{array}$ & 3.3846 & 1.2992 & 12 & 6 & 2.7692 & 1.3442 & 18 & 6 \\
\hline Many products ideas (INOV3) & 3.8431 & 1.2210 & 5 & 14 & 3.4000 & 1.3503 & 11 & 4 \\
\hline Market opportunity (INOV4) & 4.3385 & 0.9309 & 1 & 20 & 4.2769 & 0.9806 & 1 & 21 \\
\hline For children to inherit (PA1) & 2.0554 & 1.2460 & 20 & 11 & 2.2385 & 1.3854 & 20 & 3 \\
\hline Family tradition (PA2) & 1.4523 & 0.8932 & 21 & 21 & 1.6308 & 1.1147 & 22 & 17 \\
\hline Follow examples (PA3) & 2.8800 & 1.2890 & 17 & 7 & 2.8462 & 1.2787 & 17 & 9 \\
\hline $\begin{array}{l}\text { Importance in market-society } \\
\text { (REC1) }\end{array}$ & 3.8185 & 1.2201 & 6 & 15 & 3.5692 & 1.1202 & 9 & 16 \\
\hline Society’s recognition (REC2) & 2.7662 & 1.3055 & 18 & 5 & 2.6385 & 1.3119 & 19 & 7 \\
\hline Friend's respect (REC3) & 1.3046 & 0.6306 & 22 & 22 & 1.7000 & 0.9617 & 21 & 22 \\
\hline Valid N (listwise) & 325 & & & & 130 & & & \\
\hline
\end{tabular}

